\title{
The Study of the Adhesive Activity and Modification Possibilities of Melamine-Urea-Formaldehyde (MUF), Urea-Formaldehyde (UF) Resins
}

\author{
Janis Kajaks ${ }^{1}$, Arsenijs Kolbins ${ }^{2},{ }^{1-2}$ Riga Technical University
}

\begin{abstract}
Two types of thermosetting resins MUF and UF have been used as glues for birch wood veneer. As resins modifiers polyvinylacetate emulsion (PVA), polyvinylbutiral (PVB) (powder and solution), rubber latex, adipic (Ad) and sebacic (Seb) acids have been utilized. For glued system shear strength and deformation, bending properties and impact strength have been tested. The best properties: adhesive activity and elasticity have been shown by resins modified with PVB powder, rubber latex, adipic and sebacic acids.
\end{abstract}

Keywords - Adhesion, birch wood veneer, flexural and impact strength properties, melamine-urea-formaldehyde, modification, urea-formaldehyde resins.

\section{INTRODUCTION}

At present, thermosetting resins, such as melamine-ureaformaldehyde (MUF), urea-formaldehyde (UF) resins, are mainly used in plywood industry for wood veneer bonding [1] These glues are toxic and educe formaldehyde during processing and exploitation processes of laminated materials. Therefore, many researchers are forced to solve this problem [2-4]. Layers of the glue also are rather brittle and they have not sufficient elasticity [5-10]. These requirements are topical for laminated materials, which work at dynamic and impact loads, for example, skateboards. Different authors recommend different ways for improving elasticity of the resins: to add rubbers [5], to modify MUF with nanoclays [6], to add other resins-plasticizers [7, 9] and aldehydes [8]. In literature [10], to increase the chain flexibility it is offered to use dicarbonic acids. Skateboards are glued from seven birch wood veneer layers and are produced by a firm "Troja". The main problem of producers is that skateboards fracture under dynamic exploitation conditions (delamination of veneer layers and cohesive fracture of the resin layers). The aims of the current research have been to intensify adhesive interaction on the interface wood - glue, to improve elasticity of the resins and at the same time to decrease toxicity of the glues.

The study presents the results of the investigation of adhesion properties: shear strength, elongation at break, flexural strength and modulus, bending deformation and impact strength of the laminated materials glued with different modified melamineurea-formaldehyde and urea-formaldehyde resins.

\section{MATERIALS AND METHODS}

In the current research, $1.4 \mathrm{~mm}$ thick birch wood veneer was used as a substrate. MUF resins grade "Prefere 14G571" and UF resins grade "Cascorit" were modified by different modifiers: polyvinyl butyral (PVB) grade Kuraray Mowital B 60H DE10 008842 (powder and solution in butanol), polyvinyl acetate (PVA), rubber latex, adipic (Ad) and sebacic (Seb) acids. $\mathrm{NH}_{4} \mathrm{Cl}(16 \%$ solution in water) was used as a hardener. Adhesive properties were evaluated by shear strength measurements of the single overlap birch wood veneer joints [11]. Bending properties were tested for glued two veneer layer specimens (width of $2.54 \mathrm{~cm}$, length of $15 \mathrm{~cm}$ ), but impact strength was examined for specimens with width of $1 \mathrm{~cm}$ and length of $7 \mathrm{~cm}$. For all samples glued with different glues, the following properties were tested: shear strength and deformation (standard ASTM D-3164), bending strength, modulus and maximum deformation ability (standard EN ISO 178), as well as impact strength after Sharpy (standard EN ISO 179).

\section{RESULTS AND DISCUSSION}

Optimal curing technological parameters (time, temperature and pressure) of resins and modified glues were noted.

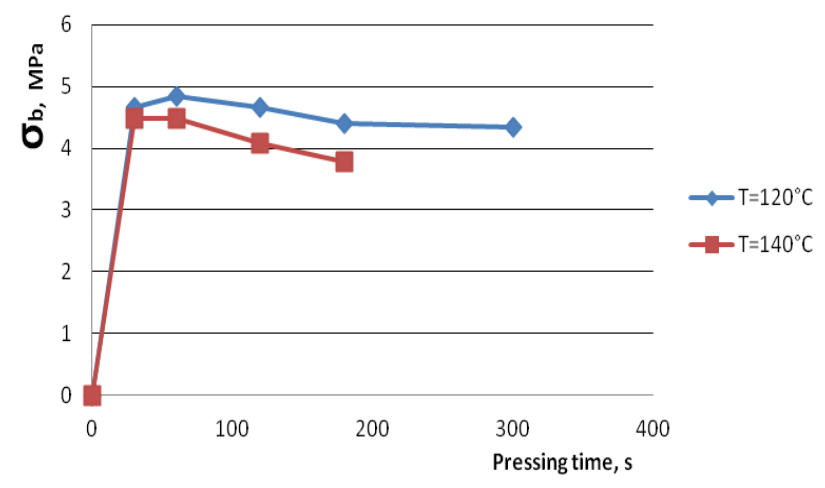

Fig. 1. Relationship between shear strength of the single lap joints of plywood and contact time at two different temperatures: $120^{\circ} \mathrm{C}$ and $140{ }^{\circ} \mathrm{C}$ using MUF adhesive. Contact pressure of $1 \mathrm{MPa}$. 
TABLE 1

RESULTS OF SHEAR AND BENDING TESTS

\begin{tabular}{|c|c|c|c|c|c|}
\hline & $\begin{array}{c}\text { Shear } \\
\text { strength, } \\
\text { MPa }\end{array}$ & $\begin{array}{c}\text { Shear deformation, } \\
\text { mm }\end{array}$ & $\begin{array}{c}\text { Bending modulus, } \\
\text { GPa }\end{array}$ & $\begin{array}{c}\text { Bending } \\
\text { deformation, } \\
\text { mm }\end{array}$ & $\begin{array}{c}\text { Bending } \\
\text { strength, } \\
\text { MPa }\end{array}$ \\
\hline MUF & 4.83 & 0.98 & 10.47 & 11.75 & 140.78 \\
\hline MUF+PVA15\% & 5.01 & 1.05 & 10.59 & 10.91 & 136.29 \\
\hline MUF+PVB(solution)15\% & 5.02 & 1.07 & 6.92 & 12.67 & 144.52 \\
\hline MUF+Latex10\% & 5.22 & 1.05 & - & - & - \\
\hline MUF+PVB(powder)20\% & 6.14 & 1.38 & 4.43 & 12.11 & 140.73 \\
\hline MUF+Seb.acid15\% & 4.55 & 1.09 & 5.54 & 12.25 & 141.49 \\
\hline MUF+Adip.acid10\% & 4.72 & 1.11 & 10.98 & 9.97 & 137.86 \\
\hline UF & 4.37 & 1.13 & 9.58 & 12.55 & 115.08 \\
\hline UF+PVA15\% & 4.91 & 1.25 & 12.06 & 9.89 & 128.75 \\
\hline UF+PVB(solution)15\% & 5.06 & 1.05 & 10.76 & 11.69 & 144.03 \\
\hline UF+Latex10\% & 5.54 & 1.28 & - & - & - \\
\hline UF+PVB(powder)20\% & 5.61 & 1.27 & 12.65 & 11.61 & 161.36 \\
\hline
\end{tabular}

It was shown that the glued samples were able to reach maximum values of the shear strength $(4.8 \mathrm{MPa}-6.2 \mathrm{MPa})$ at the contact time of $1.5 \mathrm{~min}$. -2 minutes. For example, curing kinetic of MUF resins is presented in Fig. 1. Optimal contact pressure was $1 \mathrm{MPa}$, but $t=120^{\circ} \mathrm{C}$ (for MUF and UF) and $140{ }^{\circ} \mathrm{C}$ (for $\mathrm{MUF}+\mathrm{PVB}, \mathrm{UF}+\mathrm{PVB}$ ).

It was found that the most effective modifiers of the resins were PVB powder (up to $20 \mathrm{wt} \%$ ) and latex (till $10 \mathrm{wt} \%$ ). For these modified adhesives, the maximum greatest adhesive strength and good elasticity of the adhesive layer were observed (see Table 1). Elasticity of the joints was evaluated by the elongation numerical value of the samples at the break. PVB powder from which adhesive films were prepared showed a better adhesive activity (shear strength $8.0 \mathrm{MPa}$ ) than resins modified with $20 \mathrm{wt} \%$ PVB powder $(6.14 \mathrm{MPa})$ or resins modified with PVB solution in butanol (5.03 MPa). Obviously, in this case the positive strengthening effect gave PVB curing process, during which PVB did not educe gaseous products in comparison with traditional thermosetting MUF and UF resins. Volatile products form the defects into adhesive layers and on the surface of substrate which decrease the strength of the glued joints. Presence of water (hardener $\mathrm{NH}_{4} \mathrm{Cl}$ solution) also increases the amount of the gaseous products in the layers of the glue.

Bending experiments showed that actually in all cases the modification of the glues based on UF resins improved flexural properties of the glued laminated materials, for example flexural modulus and strength. The best bending properties were gained for the samples glued with UF+PVB (powder) resins (bending modulus of $12.65 \mathrm{GPa}$ and strength of 161.36 MPa). On the contrary, MUF modified resins showed better elasticity because the samples glued with these glues fractured at the greater deformation than in the case of the modified UF resins. Practically in all cases for MUF resins flexural modulus decreased, but bending strength changed a little in limits of $+/-4 \mathrm{MPa}$, that is about $3 \%$. Better elasticity of the modified MUF resins during bending tests is somewhat strange and difficult to explain because MUF resins have greater amount of the chemically active amino groups than urea resins. Melamine has three amino groups, but urea contains only two amino groups. Therefore, melamine resins during curing process have to form more crosslink bonds among the molecules than urea resins. As a result, deformation ability has to decrease, but we have observed an opposite tendency.

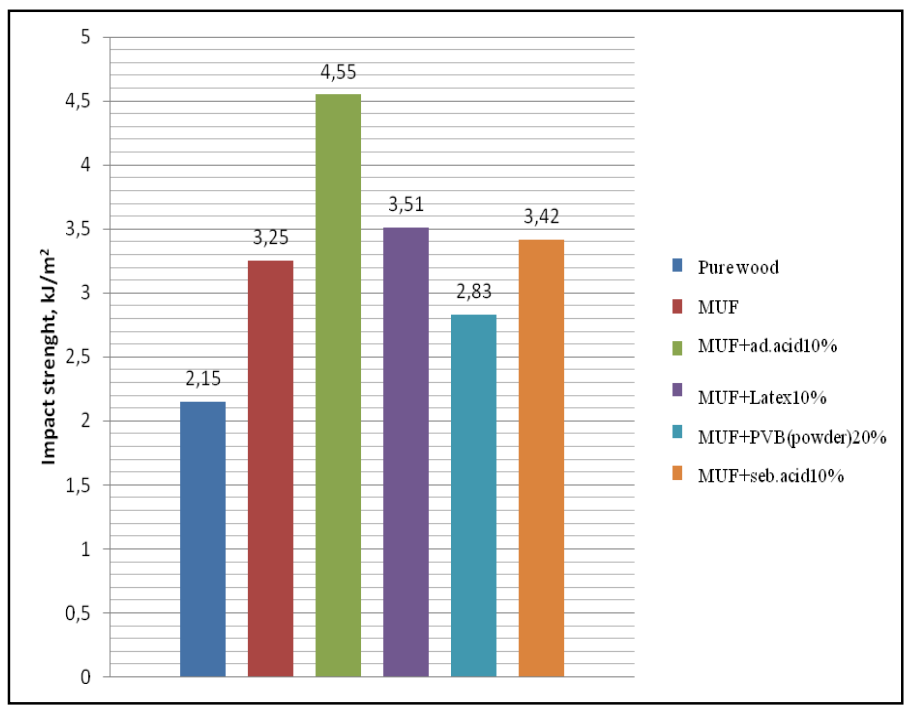

Fig. 2. Impact strength test results for wood and specimens glued with glues MUF + different modifiers.

It is a well-known fact that urea and melamine resins are cured at the presence of acid catalysts therefore we have attempted to cure resins with adipic and sebacic acids instead of traditional catalyst $\mathrm{NH}_{4} \mathrm{Cl}$. Simultaneously, the addition of organic dicarbonic acids $(10 \mathrm{wt} \%-15 \mathrm{wt} \%)$ lengthened macromolecules crosslinks, which increased the deformation ability of linked systems. Gained results were promising: shear deformation of the samples increased by about $13 \%$, flexural modulus - by about $5 \%$ (MUF+10 wt $\%$ adipic acid), bending 
strength and deformation - by about $5 \%$ (MUF+15 wt $\%$ sebacic acid) in comparison with the samples glued with resins cured with $\mathrm{NH}_{4} \mathrm{Cl}$ catalyst.

Impact strength was noted only for monolithic wood and glued veneer specimens with glues, which gave the best results at shear strength tests: MUF modified with adipic, sebacic acids, latex and PVB powder. Impact strength (A) experiments (see Fig. 2) showed the same results as in the previous studies. All glued samples had higher impact strength in comparison with virgin wood. A numerical values changed from $2.83 \mathrm{~kJ} / \mathrm{m}^{2}$ up to $4.55 \mathrm{~kJ} / \mathrm{m}^{2}$ that is more than for virgin wood $\left(2.15 \mathrm{~kJ} / \mathrm{m}^{2}\right)$. The greatest impact strength $\left(4.55 \mathrm{~kJ} / \mathrm{m}^{2}\right)$ was reached by the samples glued with melamine-urea-formaldehyde resins modified with adipic $(10 \mathrm{wt} \%)$ acid. The samples glued with pure MUF resins gave only $\mathrm{A}=3.25 \mathrm{~kJ} / \mathrm{m}^{2}$, that is smaller than that of specimens glued with modified $\mathrm{MUF}+10 \mathrm{wt} \%$ rubber latex $\left(3.51 \mathrm{~kJ} / \mathrm{m}^{2}\right)$ and MUF+15 $\mathrm{wt} \%$ sebacic acid $\left(3.42 \mathrm{~kJ} / \mathrm{m}^{2}\right)$ resins.

\section{CONCLUSIONS}

The research has shown that the best modifiers that improve the adhesive activity and elasticity of urea-formaldehyde (UF) and melamine-urea-formaldehyde (MUF) resins are polyvinyl butyral (PVB) powder, adipic (Ad), sebacic (Seb) acids and rubber latex. These modifiers give the best shear strength and shear deformation and bending properties of the glued wood veneer specimens. Modification of resins with adipic acid and rubber latex additions leads to an increase in the impact strength and gives the highest A numerical values.

\section{ACKNOWLEDGEMENTS}

The authors thank Ltd Troja for kind donation of raw materials.

\section{REFERENCES}

[1] Girod, P., Dufour, A., Rogaume, Y., Rogaume, C., Zoulalian, A. Thermal removal of nitrogen species from wood waste containing urea formaldehyde and melamine formaldehyde resnis. J. Hazard. Mater. 2008,vol.159, N (2-3), pp. 210-221.

[2] Boran, S., Usta, M., Gümüsskaya, E. Decreasing formaldehyde emission from medium density fiberboard panels produced by adding different amine compounds to urea formaldehyde resin. Int. J. Adhes. Adhes., 2011, vol. 31, N 7, pp. 674-678 http://dx.doi.org/10.1016/j.ijadhadh.2011.06.011

[3] Boran, S., Usta, M., Gümüskaya, E. The efficiency of tannin as a formaldehyde scavenger chemical in medium density fiberboard. Composites, Part B., 2012, vol. 43, N 5, pp.2487-2491. http://dx.doi.org/10.1016/j.compositesb.2011.08.004

[4] Moubarik, A., Pizzi, A., Allal, A., Charrier, F., Charrier, B. Corn starch and tannin in phenol-formaldehyde resins for plywood production. Ind. Crop. Prod.,2009, vol. 30, N 2, pp. 188-193. http://dx.doi.org/10.1016/j.indcrop.2009.03.005

[5] Kaynak, C., Cagatay, O. Rubber toughening of phenolic resin by using nitrile rubber and amino silane. Polymer Testing, 2006, vol. 25, N 3, pp. 296-305. http://dx.doi.org/10.1016/j.polymertesting.2006.01.004

[6] Zhou, X., Pizzi, A., Du, G. The effect of nanoclay on melamine-ureaformaldehyde wood adhesives. J. Adhes. Sci. Technol., 2012, vol. 26, N 10-11, pp. 1341-1348.

[7] Cardona, F., Kin-Tak, A-L., Fergio, J. Novel phenolic resins with improved mechanical and toughness properties. J. Appl. Polym. Sci., 2012, vol. 123, N 4, pp. 2131-2139. http://dx.doi.org/10.1002/app.34719

[8] Zhou, X., Essawy, H., Pizzi, A., Li, X., Rode, K., Radke, W., Du, G. Upgrading of MUF adhesives for particleboard production using oligomers of hyperbranched poly(amine-ester). J. Adhes. Sci. Technol., 2013, vol. 27, N 9, pp. 1058-1068. http://dx.doi.org/10.1080/01694243.2012.727166

[9] Zhou, X., Pizzi, A., Du, G. Enhancing MUF particleboard adhesives performance by glutaraldehyde addition. Europ. J. Wood Wood Products, 2013, vol.71, N 1, pp. 129-130. http://dx.doi.org/10.1007/s00107-012-0633-8

[10] Choi, M., Byun, H., Chung, I. The effect of chain length of flexible diacid on morphology and mechanical property of modified phenolic resin. Polymer, 2002, vol. 43, N 16, pp. 4437-4444. http://dx.doi.org/10.1016/S0032-3861(02)00226-4

[11] Kajaks, J., Bakradze, G., Viksne, A., Reihmane, S., Kalnins, M., Krutohvostov, R. The use of polyolefins-based hot melts for wood bonding. Mechanics of Composite Materials, 2009, vol.45, N 6, pp. 923-924. http://dx.doi.org/10.1007/s11029-010-9120-7

Janis Kajaks, Associate Professor, Doctor of Engineering Science at the Institute of Polymer Materials of RTU, Department of Technology of Polymer Materials. He graduated from RPI in 1969, obtained a qualification of an Engineering Technologist in plastic processing technology. He worked as a Lecturer at the Department of Polymer Processing Technology of RPI from 1969 to 1984. In 1978, he obtained a Doctoral Degree of Engineering Science and 1984 he became an Assistant Professor. In 2007, he was promoted to an Associated Professor.

E-mail: kajaks@ktf.rtu.lv

Arsenijs Kolbins, Master's degree student at the program "Material Science". In 2013, he graduated from RTU, Faculty of Material Science and Applied Chemistry and obtained his Bachelor' Degree in Material Science. Since 2013 he has been studying at the Master Study Program "Material Science".

E-mail: arsenijs.kolbins@inbox.lv

\section{Jānis Kajaks, Arsēnijs Kolbins. Melamīna-urīnvielas-formaldehīda (MUF) un urīnvielas-formaldehīda (UF) adhezīvās aktivitātes un modificēšanas iespēju pētījumi}

MUF un UF termoreaktīvos svekus loti bieži lieto koksnes līmēšanai, galvenokārt koksnes slānnaino plastiku, piemēram, saplākšna izgatavošanai. Šie sveḳi ir dabai nedraudzīgi materiāli, kas gan pārstrādes procesā, gan ekspluatācijas laikā izdala toksiskus produktus, galvenokārt formaldehīdu. Sacietējuši sveķi nav arī pietiekami elastīgi, kas ir ḷoti aktuāla problēma, ja salīmēto konstrukciju, piemēram, skrituḷlēli, ir jāslogo dinamiskos un triecienslodzes apstākḷos. Pētîjums veikts sadarbībā ar uzṇēmumu "Troja", kas ražo skrituḷēḷus no septiṇās kārtās salīmētām bērza finiera loksnēm. Ražotāju galvenā problēma ir finiera slāṇu atslāṇošanās un līmes slāṇa kohezīva sabrukšana skrituḷdẹ̣a paaugstinātas dinamiskās slogošanas apstākḷos. Pētījuma galvenais uzdevums bija ar dažādu modifikatoru palīdzību uzlabot izmantoto MUF un UF sveku adhezīvo aktivitāti, palielināt līmes slāṇa elastību un vienlaicīgi samazināt sveķu toksiskumu. Pētījumā kā sveķu modifikatorus izmantoja polivilbutirāla plēvi, pulveri un škīdumu butanolā, kaučuka lateksu, polivinilacetāta emulsiju, kā arī dikarbonskābes - adipīnskābi un sebacīnskābi. Sākotnēji noteica paraugu salīmēšanas optimālos tehnologiskos parametrus un konstatēja, ka maksimālo adhezīvo stiprību paraugiem var sasniegt jau pirmajās 1,5 līdz 2 termiskā kontakta minūtes, ja kontakta spiediens $1 \mathrm{MPa}$. Termiskā kontakta temperatūra MUF un UF sveķiem bija $120^{\circ} \mathrm{C}$; un sveḳiem, kas modificēti ar polivinilbutirālu, bija $140{ }^{\circ} \mathrm{C}$. Salīmētajiem paraugiem noteica bīdes stiprību un sagraušanas deformāciju, lieces izturību, moduli un maksimālo izlieci, kā arī vislabākajiem līmju sastāviem noteica triecienizturību. Vislielāko adhezīvo stiprību (bīdes izturību $8 \mathrm{MPa}$ ) parādīja paraugi, kas salīmēti ar tīru PVB plēvi, kuru izmantoja kā līmi-kausējumu. No modificētajām MUF un UF sveķu līmēm vislabākos adhezīvās aktivitātes un elastības rādītājus sasniedza līmes, kurām pievienotas polivinilbutirāla pulvera un kaučuka lateksa piedevas. Labi rezultāti (īpaši triecienslodzes izturības gadījumā) iegūti arī tad, ja kā sveķu modifikatorus izmanto dikarbonskābes - sebacīnskābi un adipīnskābi. 
Янис Каякс, Арсений Колбин. Исследование адгезионных своиств меламино-мочевино-формальдегидных (ММФ), мочевиноформальдегидных (МФ) смол, и возможности их модификации

Термореактивные ММФ и МФ смолы часто используются для склеивания древесины, в основном при производстве древесно-слоистых пластиков и древесно-стружечных плит. Данные смолы не являются экологически чистыми, и причиняют вред окружающей среде; во время производства и эксплуатации материалы, в которых используются данные смолы, выделяют токсичные продукты, основной из которых - формальдегид. Затвердевшие смолы также не являются достаточно эластичными, что представляет собой актуальную проблему для изделий и конструкций, подвергающихся динамическим и ударным нагрузкам, например - скейтбордов. Данное исследование проведено в сотрудничестве с фирмой „Тroja”, которая, в числе прочих продуктов, производит также и скейтборды. Скейтборды производятся из семи слоёв склееного берёзового шпона. Главная проблема для производителей - расслоение и когезионное разрушение клеевого слоя во время повышенных динамических нагрузок скейтборда. Основная цель данного исследования -улучшение адгезионных свойств смол и повышение эластичности клеевого слоя при помощи добавления различных модификаторов, и одновременное снижение токсичности смол. В качестве модификаторов были использованы: поливинилбутираль (ПВБ) (плёнка, порошок, раствор в бутиловом спирте), латекс, эмульсия поливинилацетата, так же были использованы дикарбоновые кислоты (адипиновая, себациновая). В начале исследования были определенны оптимальные технологические параметры для прессования образцов. Было констатировано, что максимальную адгезию образцы достигали уже при первых двух минутах термоконтакта, при давлении 1 МПа. Температура прессования для смол была выбрана $120^{\circ} \mathrm{C}$ и $140{ }^{\circ} \mathrm{C}$ для смол модифицированных поливинилбутиралем. Изготовленные образцы были протестированы на сдвиг (максимальная сила и деформация), изгиб (максимальная сила, деформация и модуль), так же для лучших композиций была определена ударная вязкость. Самая большая адгезионная прочность была констатирована у образцов, склееных при помощи плёнки (клей-расплава) из поливинилбутираля (сила сдвига 8 МПа). Из модифицированных ММФ и МФ смол лучшие результаты по адгезионной прочности и эластичности были получены при добавлении порошка ПВБ и латексной эмульсии, так же хорошие результаты были получены при использовании в качестве модификаторов адипиновой и себациновой кислот, особенно в случае ударной вязкости. 